Review

\title{
Liquid and Solid Embolic Agents in Gonadal Veins
}

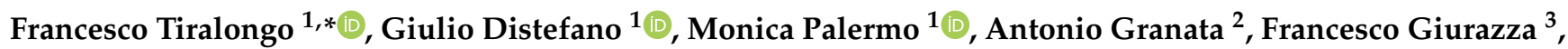 \\ Francesco Vacirca ${ }^{1}$, Stefano Palmucci ${ }^{1}{ }^{1}$, Massimo Venturini ${ }^{4}$ and Antonio Basile ${ }^{1}$
}

1 Radiology Unit I, Department of Medical Surgical Sciences and Advanced Technologies "GF Ingrassia” -University Hospital "Policlinico-San Marco", University of Catania, Via Santa Sofia n ${ }^{\circ} 78$, 95123 Catania, Italy; giuliodistefano@gmail.com (G.D.); monica.palermo91@gmail.com (M.P.); f.va77@libero.it (F.V.); spalmucci@unict.it (S.P.); basile.antonello73@gmail.com (A.B.)

2 Nephrology and Dialysis Unit, “Cannizzaro" Hospital, 95123 Catania, Italy; antonio.granata4@tin.it

3 Interventional Radiology Department, Cardarelli Hospital of Naples, 80131 Naples, Italy; francesco.giurazza@aocardarelli.it

4 Department of Diagnostic and Interventional Radiology, Circolo Hospital, Insubria University, 21100 Varese, Italyl; massimo.venturini@uninsubria.it

* Correspondence: tiralongofrancesco91@hotmail.it

Citation: Tiralongo, F.; Distefano, G.;

Palermo, M.; Granata, A.; Giurazza,

F.; Vacirca, F.; Palmucci, S.; Venturini,

M.; Basile, A. Liquid and Solid

Embolic Agents in Gonadal Veins. J.

Clin. Med. 2021, 10, 1596. https://

doi.org/10.3390/jcm10081596

Academic Editor: Paolo Gresele

Received: 17 March 2021

Accepted: 7 April 2021

Published: 9 April 2021

Publisher's Note: MDPI stays neutral with regard to jurisdictional claims in published maps and institutional affiliations.

Copyright: (C) 2021 by the authors. Licensee MDPI, Basel, Switzerland. This article is an open access article distributed under the terms and conditions of the Creative Commons Attribution (CC BY) license (https:// creativecommons.org/licenses/by/ $4.0 /)$.

\begin{abstract}
Male varicocele and pelvic congestion syndrome (PCS) are common pathologies with high predominance in young patients, having a high impact on the quality of life and infertility. Lately, the use of different endovascular embolization techniques, with various embolizing agents, shows good technical results and clinical outcomes. With the aim of presenting the "state of the art" of endovascular techniques for the treatment of male varicocele and PCS, and to discuss the performance of the different embolic agents proposed, we conducted an extensive analysis of the relevant literature and we reported and discussed the results of original studies and previous meta-analyses, providing an updated guide on this topic to clinicians and interventional radiologists. We have also underlined the technical aspects for the benefit of those who approach this type of interventional treatment. Our review suggests promising results in both the endovascular embolic treatment of male varicocele and PCS; for varicocele, a success rate of between $70 \%$ and $100 \%$ and a recurrence rate of up to $16 \%$ is reported, while for PCS it has been found that technical success is achieved in almost all cases of endovascular treatment, with a highly variable recurrence rate based on reports. Complications are overall rather rare and are represented by periprocedural pain, migration of embolic media and vascular perforations: severe adverse events have been reported very rarely.
\end{abstract}

Keywords: varicocele; pelvic congestion syndrome; embolic agent; vein embolization; interventional radiology

\section{Introduction}

Scrotal varicocele in men and pelvic congestion syndrome (PCS) in women represent two relatively frequent pathological conditions in the young-adult population, with important implications on quality of life and a significant impact on fertility. In these two conditions, gonadal venous vessels are abnormally dilated (sometimes secondary to other causes) and flow is slow and retrograde in the gonadal vein.

Traditionally, the resolutive treatment of these pathologies was based on surgery, but in recent decades interventional radiology has taken hold on this topic: there are several reports with large case series and various meta-analyses that demonstrate that, overall, transcatheter endovascular treatments are (at least) not inferior to the surgical approach, both in terms of technical and clinical success, even after prolonged follow-up, and that complications are relatively rare [1]. 
The aim of this study was to illustrate the main embolic agents used in the percutaneous treatment of male varicocele and pelvic congestion syndrome, evaluating their mechanism of action, the technical differences of use, the complications and the technical success rate and the relapse rates for each embolic agent.

We conducted an extensive analysis of the relevant literature through the PubMed and Google Scholar databases, re-evaluating previous meta-analyses, guidelines, original studies and case reports with the aim of illustrating the role of various embolic agents in male and female pathology and of providing an updated guide on this topic to clinicians and interventional radiologists. We reported the main clinical and instrumental features of scrotal varicocele and PCS and proposed a review of embolic agents, commenting on their indications, technical aspects, expected outcomes and possible complications in adult patients.

\subsection{Male Varicocele}

Male varicocele (MV) is an abnormal distension (enlargement) of the pampiniform plexus caused by reversed blood flow and/or impaired drainage of the testicular or internal spermatic vein (ISV) [2].

The incidence of varicocele in young healthy male individuals is $8-23 \%$; it involves the $40 \%$ of infertile males [3,4]. The etiology of male varicocele is multifactorial and there are three main theories to explain the onset of varicocele: (1) the left internal spermatic vein inserts into the left renal vein at an angle of $90^{\circ}$ and this angle leads to a higher hydrostatic pressure of ISV; (2) the congenital and/or acquired lack of functioning valves in ISVs which leads to reflux of blood; (3) the compression of the left renal vein (LRV) between the aorta and the superior mesenteric artery (SMA), also known as nutcracker phenomenon $[5,6]$. The left side is involved in $75-95 \%$ of cases, while the right side in only $5-10 \%$ of cases; varicocele is bilateral in $1-15 \%$ of cases [6].

Male varicocele is associated with alteration of sperm count, motility and morphology, leading to mild and moderate oligospermia, teratospermia or astheno-teratospermia [7].

With regards to symptoms, MV is often asymptomatic; local pain (in testicle, scrotum, or groin), varying from sharp to dull discomfort, scrotal heaviness and testicular volume loss are also present in about $2 \%$ to $10 \%$ [8].

Treatment is indicated in: symptomatic (painful) and palpable (grade 1-3) varicocele, in particular, persistent scrotal pain is an indication for repair, regardless of fertility status [2]; in a subclinical scenario, varicocele repair is not indicated as it does not improve spermatic parameters and does not increase the chance of spontaneous pregnancies $[9,10]$; in couple infertility, varicocele treatment has proven to be effective in men with oligospermia and unexplained infertility [11] and provides a good opportunity for natural conception [2].

Treatment consists of interruption of reflux through the ISV and its branches superior to the pampiniform plexus. This can be achieved by surgical or percutaneous endovascular techniques [12-15].

Varicocele endovascular embolization was first proposed in the 1970s and is equivalent to the surgical ISV clipping: with the Seldinger technique, through a neck, groin or arm approach, a diagnostic catheter reaches the renal vein for diagnostic phlebography. After venography demonstrates ISV dilatation and the presence of persistent collateral veins, ISV is gained and the embolic agent is directly delivered [16,17].

The procedure is performed on an outpatient basis under local anesthesia on a tilted Xray table $[15,18]$. The presence of collateral veins is the major anatomical factor contributing to treatment failure [19]. Radiologic treatment offers the advantages of causing less patient discomfort and rapid recovery in comparison to the more invasive approach of varicocelectomy [20]. Endovascular treatment offers a lower cost and a lower recurrence rate than surgery and prevents the incision and splitting of the abdominal muscles [14,21-24]. 
In addition, surgery does not provide the possibility to visualize the exact varicocele anatomy and collaterals [25]. Concerning open varicocelectomy techniques, high recurrence and complication rates have been reported, with complications ranging from hydrocele formation, testicular artery injury, epididymitis, and vas deferens occlusion, which are otherwise rarely seen in the endovascular approach [26].

\subsection{Pelvic Congestion Syndrome}

Pelvic congestion syndrome (PCS) is a pathological condition characterized by chronic pelvic pain (CPP, defined as pain lasting at least six months associated with symptoms indicating gynecologic, lower urinary tract, bowel, and pelvic floor dysfunction) and retrograde flow in ovarian veins, which appear dilated, and para-uterine varices [27,28]. CPP is associated with pelvic varicocele in about $30 \%$ of cases, particularly in pre-menopausal multiparous women with no other known causes of pelvic pain [28].

This condition can be primitive, because of the lack of valves (15\% of cases) or of the presence of incompetent valves (up to $40 \%$ of cases), monolaterally or bilaterally [29], or it may be secondary, due to extrinsic compression of upstream venous vessels, as occurs in anterior or posterior Nutcracker syndrome (for the LRV) entrapment [30] or in May-Thurner syndrome (for the left common iliac vein compression) [31].

The diagnosis is made on the basis of the clinical features and imaging tests.

Clinically, PCS is associated with a feeling of heaviness, that can be exacerbated during menstruation and pregnancy, by coitus (dyspareunia) or by physical activity; gastrointestinal disorders, bladder irritability and menstrual disorders may also be present [32]. Angiographic findings include gonadal vein reflux, dilatation of gonadal, uterine and utero-ovarian vein (diameter greater than $5 \mathrm{~mm}$ ), contralateral reflux, opacification of vulvar varices, and a reno-caval gradient of $>4 \mathrm{mmHg}$ [33]. In order to stage the pathology through the score system proposed by Beard [34], the maximum diameter of the ovarian vein, timing of disappearance of contrast medium, and the degree of congestion should be carefully evaluated.

Indications for treatment include pelvic varicosities associated with clinical feature of PCS, symptomatic labial/perineal varicosities, lower-limb varicosities with atypical distribution or which recur immediately after treatment, and unexplained CPP in patients with varicosities.

The treatment of PCS includes medical, surgical and interventional radiology techniques; the latter have proved to be not inferior to traditional surgery, with the benefit of being less invasive, less expensive and better tolerated by the patient [35]. Secondary forms due to narrowing of LRV can be treated with stent placement at the stenotic tract [30].

\section{Embolic Agents}

Embolic agents can be classified on the basis of their physical state (solid vs. liquid), mechanism of action (mechanical vs. chemical), origin (autologous vs. synthetic) and on the duration of occlusion (temporary vs. permanent) [36]. In this narrative review, we focus on the different physical state of embolic agents used in gonadal veins (Table 1).

\subsection{Solid Agents}

Solid embolic agents include devices that provide mechanical embolization; they are distinguished in coils, vascular plugs and balloons.

In 1975, Gianturco et al. [37] introduced the use of coils for embolotherapy; over the years, different configurations have been proposed, with a wide variety of shapes (straight, helical, spiral and 3D shapes) and sizes (the length can range from 1 to $300 \mathrm{~mm}$ and the diameter from 1 to $27 \mathrm{~mm}$ ). In order to increase the thrombogenity, they can be coated with different materials like Dacron, nylon or silk fibers. Coils can be delivered by pushing or by using a specific detachment system. While pushable coils are less expensive and allow a quicker procedure, using detachable coils make their placement more accurate and 
predictable. It should be recalled that the effectiveness of the coil embolization depends on the patient's coagulation state [38].

Table 1. This table summarizes embolic agents used in gonadal veins embolization.

\begin{tabular}{|c|c|c|}
\hline \multicolumn{3}{|c|}{ Gonadal Veins Embolic Agents } \\
\hline & Materials & Mechanism of Action \\
\hline \multicolumn{3}{|c|}{ Solid Embolic Agents } \\
\hline Coils & Platinum or stainless steel & $\begin{array}{c}\text { Permanent Mechanical Thrombogenicity } \\
\text { Platelets activation }\end{array}$ \\
\hline Vascular Plugs & Disks of self-expanding nitinol mesh & Permanent Mechanical \\
\hline Balloons & Detachable balloons, occluding balloons & Permanent Mechanical \\
\hline \multicolumn{3}{|c|}{ Liquid embolic agents } \\
\hline Glues & $\begin{array}{c}\text { N-butyl-cyanoacrylate } \\
\text { (NBCA)N-butyl-cyanoacrylate }+ \\
\text { methacryloxysulfolane, (NBCA-MS) }\end{array}$ & $\begin{array}{l}\text { Polymerization in contact with blood } \\
\text { Exothermic reaction } \\
\text { Damage of the vascular endothelium }\end{array}$ \\
\hline Sclerosing agents & $\begin{array}{c}\text { Polidocanol } \\
\text { Sodium tetradecyl sulfate (STS)Sodium morrhuate } \\
\text { Ethanolamine oleate }\end{array}$ & $\begin{array}{l}\text { Polymerization in contact with blood } \\
\text { Venous wall damage } \\
\text { Occlusion of the vessel }\end{array}$ \\
\hline Ony $x^{\circledR}$ & Ethylene-vinyl alcohol (EVOH) & $\begin{array}{l}\text { Polymerization in contact with blood } \\
\text { Solidification to a rigid cast }\end{array}$ \\
\hline
\end{tabular}

The Vascular Plugs (AVPs) are permanent mechanical embolic devices. They are disks of self-expanding nitinol mesh and they are suitable especially in high-flow vessels, providing a lower risk of migration than coils. Different types of AVPs present different morphology and sizes, each one fitting with specific application. Releasing an AVP is relatively easy for the operator, thanks to the delivery wire that is associated to a stainlesssteel micro screw, which allows the radiologist to retrieve and reposition the plug before the final release, that is obtained by rotating the wire with a torque device. AVPs are relatively expensive but can significantly reduce procedure time. Like coils, AVPs depend on a patient's coagulation status to obtain a successful embolization [38,39].

Detachable balloons are mechanical embolic devices $[40,41]$. The balloon should be chosen slightly larger than the diameter of the vessel to be occluded and they are attached to their delivery catheters and, if it is large enough, two balloons can simultaneously be advanced through it into the vessel in order to reduce the risk of premature detachment. The proximal balloon is used to arrest the flow and removed after the distal balloon is deployed-its use is nowadays not common.

\subsection{Liquid Agents}

Liquid embolic agents include tissue adhesives, also known as glues (N-butyl-cyanoacrylate, NBCA, or N-butyl-cyano-acrylate + methacryloxysulfolane, NBCA-MS) and sclerosing agents prepared as foam or liquid (e.g., polidocanol, sodium tetradecyl sulfate, sodium morrhuate, or ethanolamine oleate), the latter often used in combination with coils and/or balloons (sclero-embolization).

Cyanoacrylate is a glue with a high adhesive strength, approved by the Food and Drug Administration (FDA) in 1998 for trauma and surgery injuries [42,43]. After contact with blood, it starts a polymerization that triggers an exothermic reaction that contributes to the damage of the vascular endothelium. Cyanoacrylate has a dual mechanism of action: as an embolic agent and as a sclerosing agent [22]. There are several chemical forms, depending on the chemical chain (methyl, ethyl, n-butyl, isoamyl, isohexyl, and octyl cyanoacrylates) [44]. 
Cyanoacrilate is radiolucent, so it should be mixed with Lipiodol and released under fluoroscopic control. The mixture with Lipiodol also modulates the polymerization rate [45]. As reported in literature, a mixture at a ratio of 1:1 allows to achieve a rapid polymerization that avoids migration $[19,45]$. Classic NBCA (Histoacryl ${ }^{\circledR}$, Braun, Melsungen, Germany) has a polymerization temperature of $90^{\circ} \mathrm{C}$ and a polymerization time rate $<30 \mathrm{~s}$. In 2001, a new tissue adhesive system came on the market as NBCA-MS or N2BCA (Glubran ${ }^{\circledR}$ 2, General Enterprise Marketing, Viareggio, Lucca, Italy) [46]. It is composed by two adhesives, consisting of the same monomer as NBCA (n-butyl-2-cyanoacrylate) with the addition of a co-monomer (methacryloxysulfolane), and a different way of polymerization [14,47]. With Glubran2, the polymerization rate is slower, and the handling and releasing are easier. The exothermic reaction is weaker $\left(45^{\circ} \mathrm{C}\right)$, resulting in lesser inflammation and histotoxicity than when Histoacryl ${ }^{\circledR}$ is used, and therefore it is less painful at the time of injection. The final polymer is more flexible than conventional cyanoacrylate. Glubran2 has a bacteriostatic effect and does not polymerize in contact with air; it is the only glue with a CE-mark for endovascular use $[14,15,19,45]$.

Vanlangenhove et al. tested Histoacryl ${ }^{\circledR}$ and Glubran ${ }^{\circledR} 2$ in a double-blind, prospective, randomized study: they found that both glues can be handled in the same way and that the embolic result is similar [15].

Sclerotherapy is a powerful and commonly used embolic technique; it refers to the introduction of a foreign substance into the lumen of a vessel, aiming to create venous wall damage leading to occlusion of the vessel [48].

Sclerosing agents work by causing irreversible damage to the venous wall by attacking lipids and cellular walls - the inflammatory response is a result of cell damage with fibroblast proliferation that leads to sclerosis. In addition to fibrosis, agents may produce other effects such as thrombosis, extraction of proteins from lipids, denaturation of proteins, cell dehydration by osmosis, and physical obstruction by polymerization [49]. Various sclerosing agents have been described, including osmotic agents, detergents, chemical agents, and erosive agents. In particular, detergents are used in gonadal veins embolization. Detergents act by disrupting cell membranes through the mechanism of protein theft denaturation. Endothelial damage occurs within minutes of the administration of these agents and can spread farther from the injection site. The advantages of detergents are that their concentrations can be adjusted to match the size and type of vessel being treated and they can be made into foam. Common detergent sclerosants include polidocanol (Aetoxysclerol ${ }^{\circledR} 1-2$ ), sodium tetradecyl sulfate (STS), sodium morrhuate, and ethanolamine oleate. Frequently, sclerotherapy is performed by mixing air or oxygen into the sclerosant, known as foam sclerotherapy [50].

A particular liquid agent is Onyx ${ }^{\circledR}$ (ev3, Irvine, CA, USA), a liquid non-adhesive embolic agent, also known as ethylene-vinyl alcohol (EVOH). Onyx is a biocompatible copolymer dissolved in dimethyl sulfoxide (DMSO) that, when in contact with blood, solidifies to a rigid cast, as a kind of plastic, and can be then pushed and extended in different directions [51,52].

\section{Clinical Results in Male Varicocele}

Male varicocele embolization can be achieved using solid and liquid embolic agents. Solid embolic agents for treatment of male varicocele embolization include coils, detachable balloons, vascular plugs.

More than 30 years ago, coils were introduced by Thelen et al. [53] and they showed to be effective in varicocele treatment. Coils-embolization is the most commonly used technique, due to coils simplicity in handling and availability [54]. Initially, the original 0.038 inch Gianturco coils were used; subsequently, fibered stainless-steel coils and platinum coils were developed, ranging from 0.035 to 0.038 inches and oversized up to $20 \%$. Coils can be pushable or detachable, the latter improve correct placement [53]. During embolization procedures, coils are first deployed through the microcatheter as distal as possible and up to the inguinal canal. Then, a sandwich occlusion of the spermatic vein is 
performed with additional coils in the proximal part of the spermatic vein (Figure 1) [45]. The coils deployment is carried out during Valsalva maneuver in order to have the maximum diameter of ISV. The main disadvantage of coils is that they are not as effective as the surgical clipping if collateral vessels are present $[25,53,55]$ : this can lead to the recanalization of the varicocele [45].

Coil embolization has been shown to lead to several complications; in particular, epididymo-orchitis, pampiniform plexus phlebitis or hydrocele were the most common complications, observed in $3.4 \%$ of the patients [56]. An episode of femoral phlebitis was reported and treated on an outpatient basis [57]; moreover, one episode of coil migration in right atrium was reported: coil was immediately captured and retrieved [56]. Coil migration may cause pulmonary embolism, but this kind of complication is almost nil thanks to the development of detachable coils [45]. Bilrerio et al. reported a rate of complication of $0.97 \%$ with coils, significantly lower than the $9.7 \%$, reported by Bechara et al. [20,58]. Makris et al., in a systematic review including 898 patients treated with coils and 1628 patients treated with a combination of coils and sclerosing, reported a mean technical success rate of $92 \%$ for both coils group and coils + sclerosing group, with an average relapse rate of $9.1 \%$ for coils group and $8.44 \%$ for combined treatment (without significant difference between the two groups) [56].

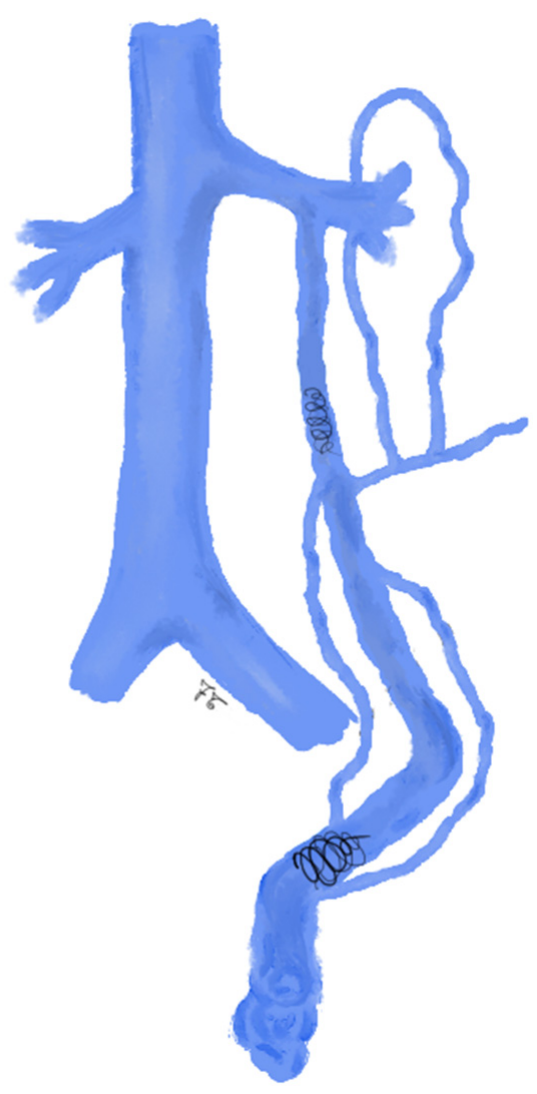

Figure 1. Drawing shows spermatic vein embolization with coils: coils are first deployed as distal as possible and up to the inguinal canal. Then, a sandwich occlusion of the spermatic vein is performed with additional coils in the proximal part of the spermatic vein.

A further factor to be evaluated in coil embolization is the failure rate due to technical fault, ranging from 3 to $28 \%$ [15]: this issue is related to the difficulty in catheterizing the spermatic vein in case of aberrant vessels, valves, vasospasm and intimal dissection $[53,59,60]$. 
Amplatzer vascular plugs may be used as an alternative to coils [61]; both plugs and coils were used to ensure complete occlusion of the spermatic vein through the sandwich technique. In cases of large veins, both plugs and coils were used in combination to ensure complete occlusion of the spermatic vein [45].

Detachable balloons can be navigated through an introducer catheter and detached in the ISV. Depending on the size of the varicocele and on the presence of collateral vessels, one or more 1 or $2 \mathrm{~mm}$ detachable balloons can be used. Balloons are frequently used in combination with other agents, like coils or sclerosing agent-like sandwiched $70 \%$ dextrose [18].

Liquid agents, despite solid agents, have the advantage of being able to penetrate into the collateral venous network around the ISV.

Tissue-adhesives (Cyanoacrylates) were first introduced in varicocele treatment by Kunnen et al. in 1980. The first used glue was a mixture of contrast agent and isobutyl-2cyanoacrylate, IBCA (Bucrylate, Ethicon) [21]. Due to its possible carcinogenicity, IBCA was later replaced by NBCA (n-butyl-2-cyanoacrylate or Embucrilate; Histoacryl Transparent, Braun, Tuttlingen, Germany), which, however, never received a European conformity (CE) label for intravascular use, followed by Glubran 2-the only glue with a CE-mark for endovascular use [62-64]. Glue should be injected immediately after an injection of an anionic solution (5-10\% dextrose solution) in order to fill the catheter dead space and avoid glue polymerization into the catheter lumen [58].

The glue is sequentially injected through the microcatheter and pushed into the distal intrapelvic segment of the gonadal vein as well as into the collaterals; the catheter should be withdrawn while injecting the glue under fluoroscopy guidance. Injection should be stopped before the pampiniform plexus is reached (Figure 2) [45]. As soon as the glue comes in contact with blood, the polymerization process starts, and a permanent occlusion of the vessel occurs [15]. As already mentioned, liquid agents, unlike non-liquid ones, have the advantage of affect also the collateral pathways, thus increasing the effectiveness of the procedure $[26,65]$.

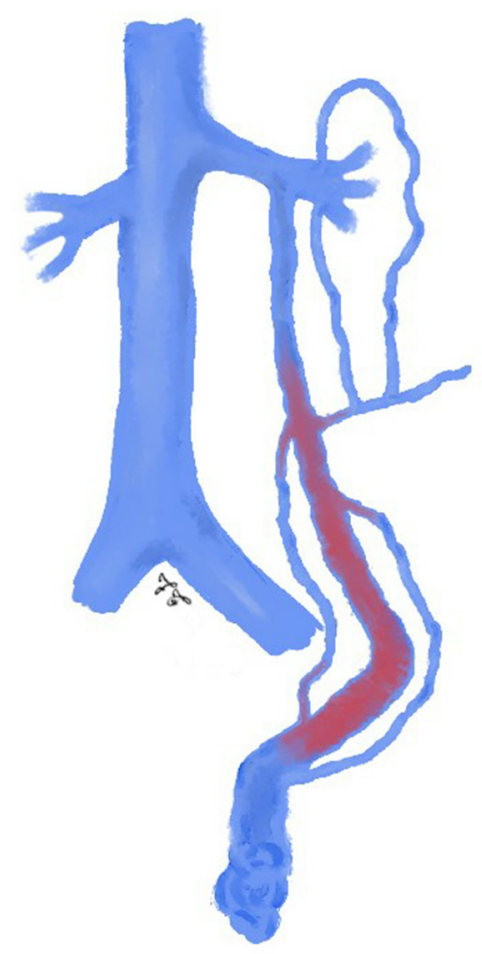

Figure 2. Drawing shows spermatic vein embolization with glue: glue is sequentially injected and pushed into the distal intrapelvic segment of the gonadal vein as well as into the collaterals; injection should be stopped before the pampiniform plexus is reached. 
Cyanoacrylate glue for varicocele embolization was shown to be a safe and effective alternative to coils [58]; in particular, the mean procedure time was shorter with glue, resulting in a lower radiation (shorter duration of scopy, less kinetic energy released per unit mass, lower DAP) [45]. Embolization with glue is also cost-effective: one cubic centimeter has a comparable cost of single conventional pushing-coil, but it is sufficient for a successful treatment in the majority of cases [19]. N2BCA has also a cosmetic advantage, as it is absorbed over time and does not appear in diagnostic images [19].

The main disadvantage of glue is that its release is not fully controllable by the operator [19]. Cyanoacrylate varicocele embolization has been reported with some complications: the most common was the perforation of the ISV with contrast extravasation (5.8\% of patients), with no increase in the need for reintervention [56]; other reported complications are glue migration into pulmonary circulation, glued catheter, phlebitis of pampiniform plexus and ISV and post-embolization pain $[26,45,56,65,66]$.

Vanlangenhove et al. reported a late inflammatory reaction to the cyanoacrylates: during the week after embolization, $59 \%$ of patients reported some discomfort, which was in 35\% at least a bearable pain [15]. Many studies report a technical success rate of $92 \%$ for glue embolization of male varicocele [56], with a lower recurrence rate $(4.2 \%)$ than other embolic agents due to the penetration into the collaterals and a low technical failure rate $(<1 \%)$ related to the use of a coaxial catheter system [15].

Percutaneous sclerotherapy of varicocele was first introduced by Porst et al. in 1984 and it could be considered the standard and most frequent percutaneous approach for MV [26,67]. In Europe, sodium tetradecyl sulfate 3\% (STS), sodium morrhuate, dextrose, hydroxypolyethoxydocanol and polidocanol (Aetoxysclerol ${ }^{\circledR} 1-2$ or $3 \%$, Kreussler Pharma, Paris, France) [68] are the most common sclerotic agents. The Sclerosing agent can be used alone or in combination with coils or balloon $[19,25,45]$ and can be injected as a liquid or as foam [15]. Foam sclerotherapy has been considered to offer several advantages over traditional liquid sclerotherapy [57]. The foam has the advantage of a better distribution of the sclerosing agent on the endothelial surface and of multiple collateral branches, resulting in a more effective embolization [69].

The sclero-embolization technique consists of injecting a sclerosing agent, as a pure liquid or mixed with air as foam, into the distal portion of the ISV $[15,25,45,69]$. The sclerosing agent is prepared in foam by mixing the contents of two syringes, one containing the sclerosing agent and the other containing unfiltered room air, according to Tessari et al. [70]; some authors use a ratio of 1:1 (air and sclerosing), adding $2 \mathrm{~mL}$ of contrast media to create the foam [25,45], others use 70\% of sclerosing agent and 30\% of air [69]. Before injecting the sclerosing agent, a distal barrage near the external inguinal ring is mandatory to prevent the agent from penetrating into the pampiniform plexus during Valsalva maneuver, hence avoiding inflammation and thrombosis (thrombophlebitis) of the pampiniform plexus; for this purpose, some authors place coils at the level of the inguinal canal [45], while others use manual compression [15] or rubber band applied at the highest level of the scrotum, kept in place for $10 \mathrm{~min}$ after sclerosing injection and then released [69]. The sclerosing agent is administered under fluoroscopic guidance, through a catheter whose tip is placed in the most distal part of the ISV, at the level of the sacroiliac joint or at the lower edge of the ischiopubic ramus $[15,45]$.

During the injection, the patient should perform the Valsalva maneuver to prevent the sclerosing agent refluxing into the renal vein $[15,45]$. In case of other collateral veins originating below the sacroiliac joint, the catheter should be positioned at the level of their origin, to allow the extensive sclerotherapy of all collaterals $[15,45]$. Some authors suggest deploying additional coils at the proximal part of the spermatic vein according to the sandwich technique (Figure 3) [45]. 


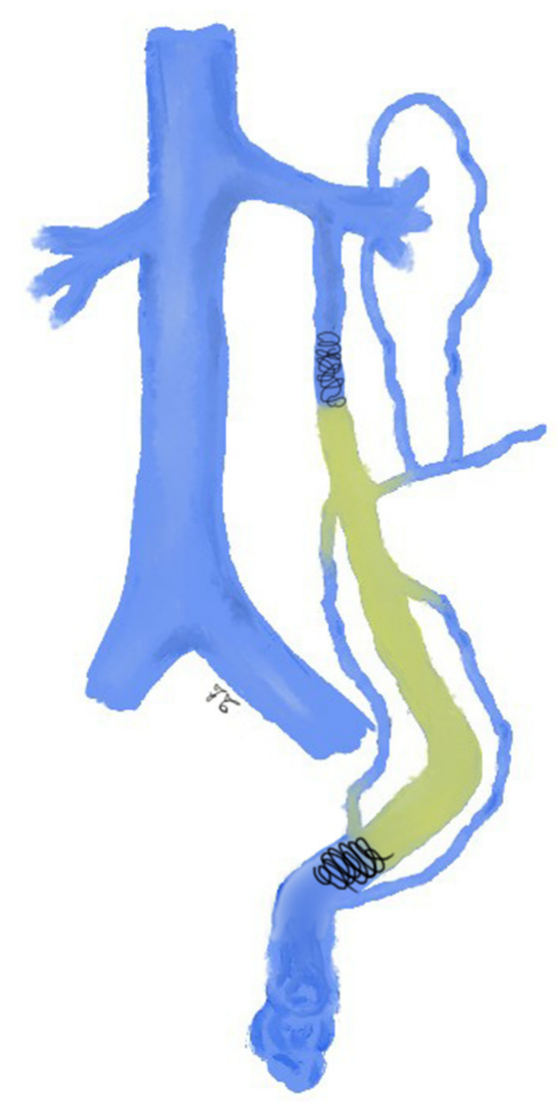

Figure 3. Drawing shows spermatic vein embolization with sclerosing agent: the sclerosant is administered through a catheter whose tip is placed in the most distal part of the ISV, at the level of the sacroiliac joint. Additional coils are deployed at the proximal part of the spermatic vein according to the sandwich technique.

Basile et al. propose a variation to traditional sclerosing technique, similar to the balloon-occluded retrograde transvenous obliteration (BRTO) technique for gastric varices treatment [71]. This technique, also known as "OB technique", refers to the use of a temporary proximal $\mathrm{OB}$ catheter in addition to distal barrage, to stop the retrograde blood flow: the sclerosing agent is injected through the $\mathrm{OB}$ catheter into the distal portion of the ISV without any Valsalva maneuver (Figure 4). Through the OB technique, the sclerosing agent becomes more controllable during its injection and remains in constant contact, at highest concentration, with the vessel walls [69].

The advantage of Sclerosing agents is that they spread beyond the main gonadal vein through the collaterals, thus preventing possible recurrence $[15,19,25,45]$, but their low viscosity and visibility might increase nontarget embolization [15]. Sclerotherapy improve testicular function and seminal parameters, increasing sperm density, motility and morphology [59,72-74], and also pregnancy rates (39\%), as described by Gandini et al. [73].

A disadvantage of the sclerosing agents use, in case of free catheter injection, is that agents' concentration into the vessels is related to the patient's ability to maintain Valsalva maneuver; in cases where the patient is unable to hold a deep Valsalva or in patients with pain or sedation, the sclerosing agent can be diluted and so its effectiveness is decreased. To overcome this problem, $\mathrm{OB}$ technique could be used, as it does not require Valsalva maneuver and could be even more comfortable for patients [69].

Fever, epididymo-orchitis, testicular or groin swelling and hydrocele were observed in $1.9 \%$ of patients; these were the most frequently encountered complications, followed by spermatic vein rupture and extravasation $(0.9 \%)$ and allergic reactions $(0.2 \%)$ [56]. In case of manual compression used as distal barrage, pampiniform plexus thrombophlebitis was reported as the most common complication, due to an insufficient manual compression 
of the inguinal ring during injection, allowing the sclerosing to pass in the pampiniform plexus [25].

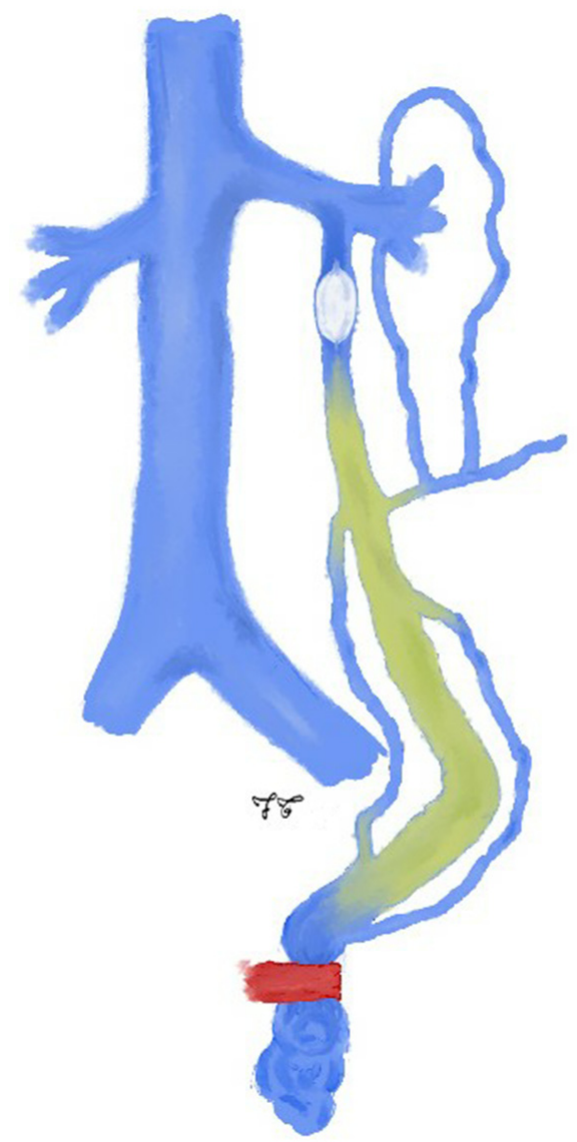

Figure 4. Drawing shows spermatic vein embolization with sclerosing agent according to occluding balloon technique: this technique refers to the use of a temporary proximal OB catheter in addition to distal barrage, to stop the retrograde blood flow. The sclerosing agent is injected through the OB catheter into the distal portion of the ISV.

Scleroembolization of MV presents a technical success rate of $92.5 \%$ and a relapse rate of $11.03 \%$ [56]. Ali et al. reported that $94.9 \%$ of patients refer a complete resolution of pain or discomfort and in $97 \%$ of cases the resolution of testicular swelling or palpable "bag of worms". Sclerotherapy with polidocanol presented higher pregnancy rates than surgical treatment options and has the advantage of no association with hydrocele [25]. Transcatheter embolization with sclerosing agent can be considered the most effective and safe procedure for treatment of MV and may be the preferable treatment option for patients with unilateral varicocele [23].

Vanlangenhove et al. tested Onyx as an embolic agent in ISV embolization and found that Onyx was efficient and indeed better tolerated in the post-embolization period, but there was an acute pain reaction during the injection in most patients. Patients' discomfort and high radiation dose preclude, at the moment, Onyx clinical use [15].

The previous publications taken into consideration, the embolic materials used, the technical success rate, the recurrence rate and complications for male varicocele are summarized in Table 2. 


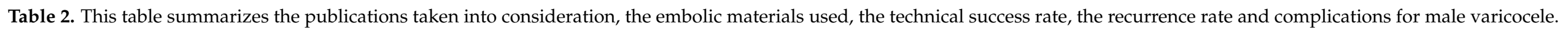

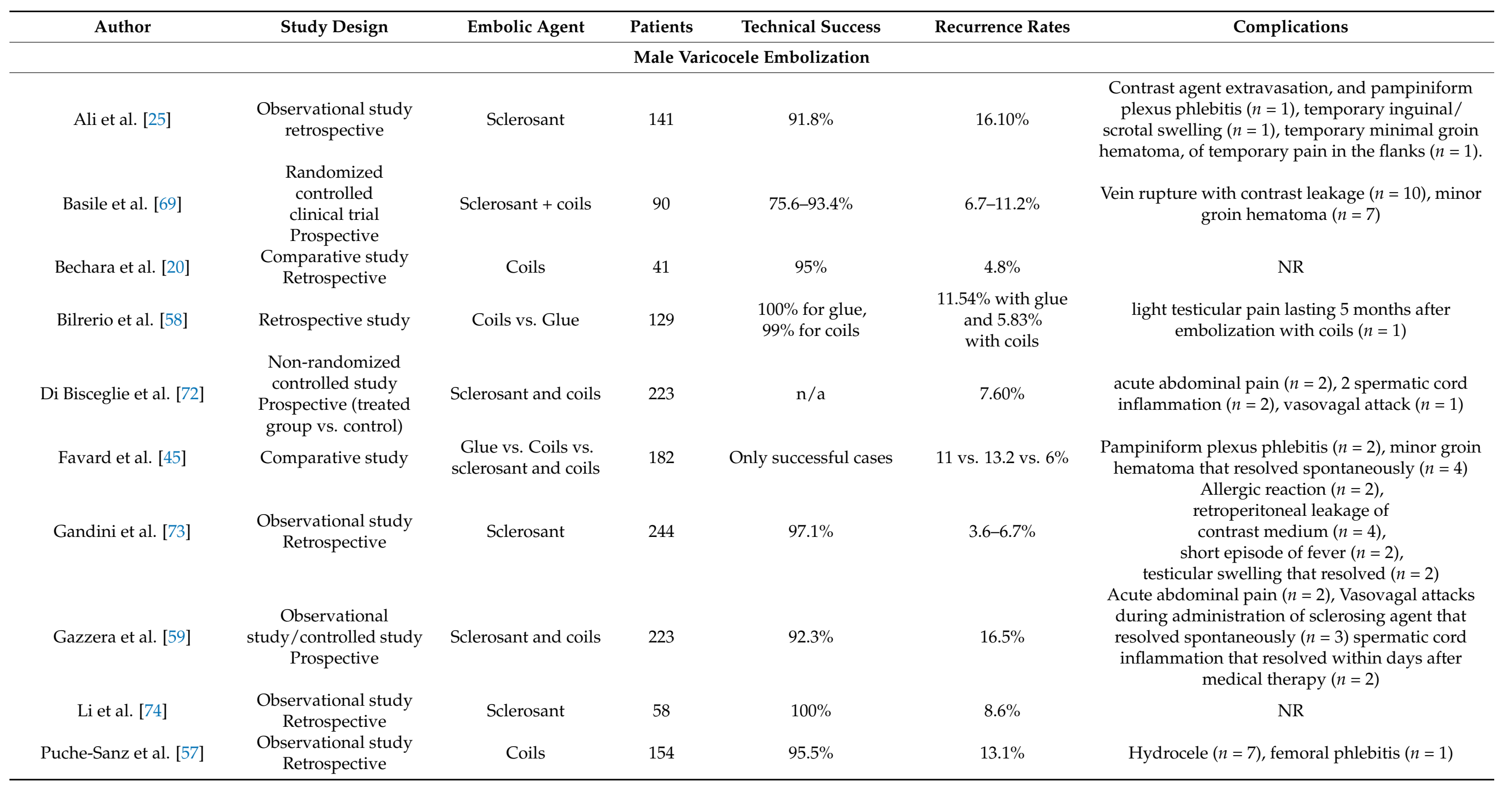


Table 2. Cont.

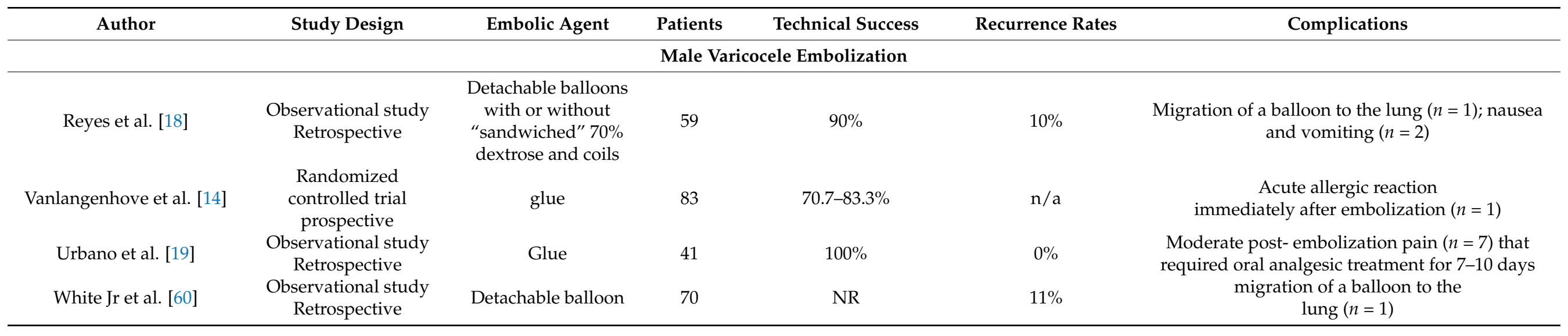




\section{Clinical Results in Pelvic Congestion Syndrome}

Trans-catheter endovascular embolization technique allows a permanent vascular occlusion of the uterine and pelvic veins with multiple embolic agents; in literature, treatments have been reported with both liquid agents and solid agents such as coils and plugs, that can be used alone or in combination [75]. In general, the choice of the embolic agents is up to operators' experience and preferences, since clinical and technical success rates are high for all of them. Endovascular treatment is essentially aimed at treating ectatic vessels; there is no agreement in the literature on how many vessels should.

Regarding the technical aspects, some authors suggest that the release of coils should begin at the lower aspect of the ovarian vein, trying to avoid the occlusion of the deep pelvic plexus; stainless steel or fibered platinum coils of several sizes $(4-20 \mathrm{~mm}) \mathrm{can}$ be used (Figure 5) [76]. In expert hands, a technical success of $100 \%$ has been reported, and a recent systematic review reports that partial or total clinical improvement (evaluated with VAS score at follow-up) following coils embolization ranges from $82.1 \%$ to $100 \%$ [77].

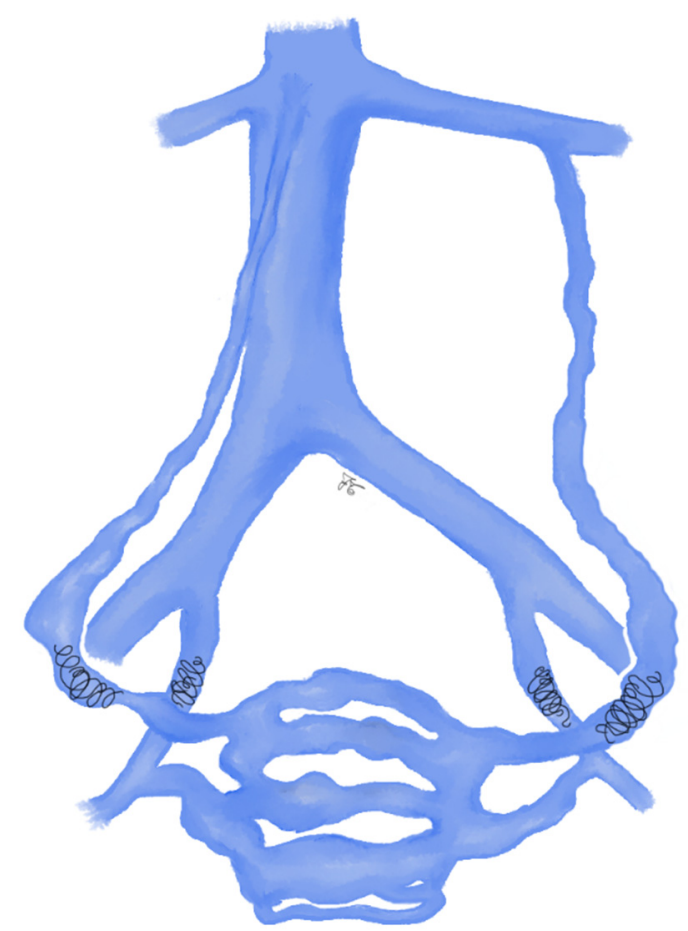

Figure 5. Drawing shows left and right ovarian veins and left and right hypogastric veins embolization with coils, as reported by Laborda et al. [76].

The main complications are represented by migration of the coils (described in $1.9 \%$ of cases) followed by coil misplacement, vein perforation, local phlebitis, and re-canalization because of coil erosion; most adverse events are early, and no significant complications have been reported on prolonged follow-up [76].

The use of Amplatzer vascular plug (AVP) for embolization of the ovarian vein has been reported in the literature by Basile et al.; these authors used AVPs of $12 \mathrm{~mm}$ and $14 \mathrm{~mm}$ on a patient who was symptom-free after a nine-month follow-up; the authors reported that the positioning of these devices was relatively simple and fast, with possible reduction of radiation exposure [78]. Although this technique seemed to be promising, there are no other similar case reports to the best of our knowledge.

Gelfoam can be administered by freehand injection or with the aid of an occluding balloon (OB) angiographic catheter [35]. The target vein and the catheter should be prefilled with iodinated contrast and later the foam should be slowly injected, replacing the contrast in the target vessel in order to ensure the perfect vessel coverage and reduce the reflux. Studies reported in the literature have always used gelfoam in combination with 
other embolizing agents (coils, glues), and therefore it is not possible to comment on the efficacy of gelfoam as the only embolizing agent in the treatment of PCS [77,79].

Liquid agents that have an application on PCS treatment are sclerosing agents (polidocanol, tetradecyl sulfate, sodium morrhuate), lipiodized oils, alcohol and glues.

Embolization with glues, possibly in association with coils, is a valid alternative in the treatment of PCS. Enbucrilate, also known as n-Butyl cyanoacrylate, n-BCA or NBCA, is a liquid embolic system, composed of cyanoacrylate, which is usually administered mixed with lipiodized oil to increase its radiopacity.

NBCA embolization, alone or in association with coils, for the treatment of PCS was first described by Capasso et al. in 1993 [80]. As reported in literature, the procedure is performed in a one-day-clinic setting; the patient should be placed in a semi-upright position, in order to reduce the risk of glue migration into the systemic circulation, eventually performing a Valsalva maneuver [81]. Embolization should start from the distal portion of the ovarian vein at the level of the upper half of the sacroiliac joint, to include possible collateral branches (Figure 6) [80]. The technical success rate of embolization with NBCA is between $96.7 \%$ and $98 \%$, with total or partial relief of symptoms in $57.9 \%$ and $15.8 \%$ of cases in follow-up, respectively $[80,81]$. No significant differences were found in symptom relief in patients with mono or bilateral disease, nor as a function of parity, and the presence of initial dyspareunia does not affect the results [81]. The main complications of this embolization technique are the glue migration into the pulmonary circulation, described in two cases by Maleux et al. and the perforation of the vessels caused by the guidewire, described in two cases by Capasso et al. [80,81].

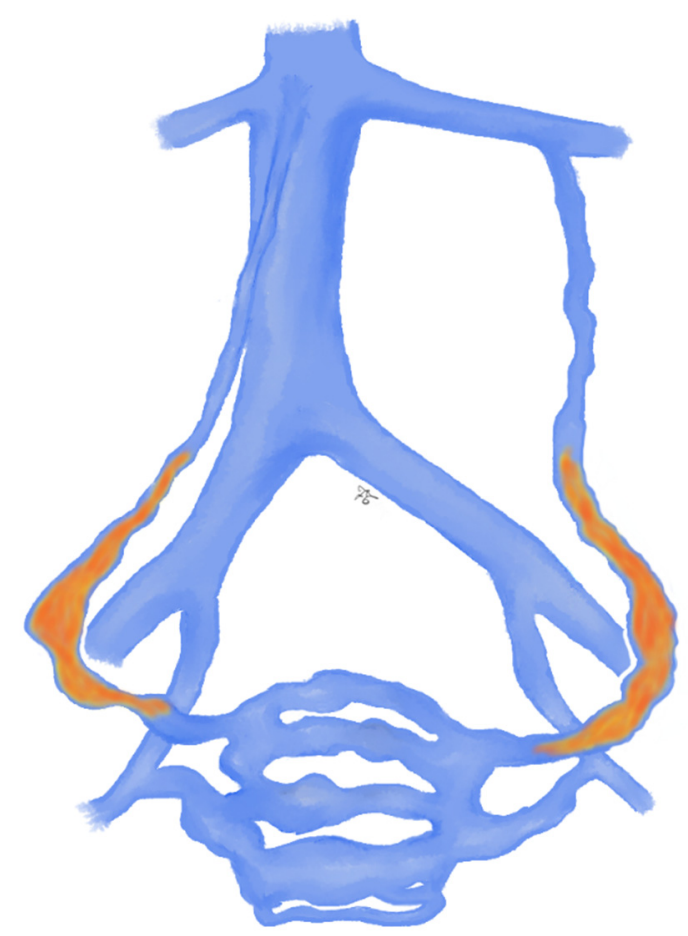

Figure 6. Drawing shows left and right ovarian veins embolization with glue: embolization should start from the distal portion of the ovarian vein at the level of the upper half of the sacroiliac joint, to include possible collateral branches.

Sclerosing agents have also been used in PCS: as far as we know, sodium tetradecyl sulfate and sodium morrhuate were used in reproducible studies with a sufficiently detailed protocol.

Regarding the technique details, Gandini et al. reported that they performed stopflow foam sclerotherapy (SFFS) using $20-40 \mathrm{~mL}$ of $3 \%$ STS (sclerosing agent), which was injected into the pelvic vessels after having inflated the balloon catheter to occlude the 
major tributary vessels (hypogastric and/or ovarian veins) and excluding high-outflow venous collaterals (Figure 7) [82].

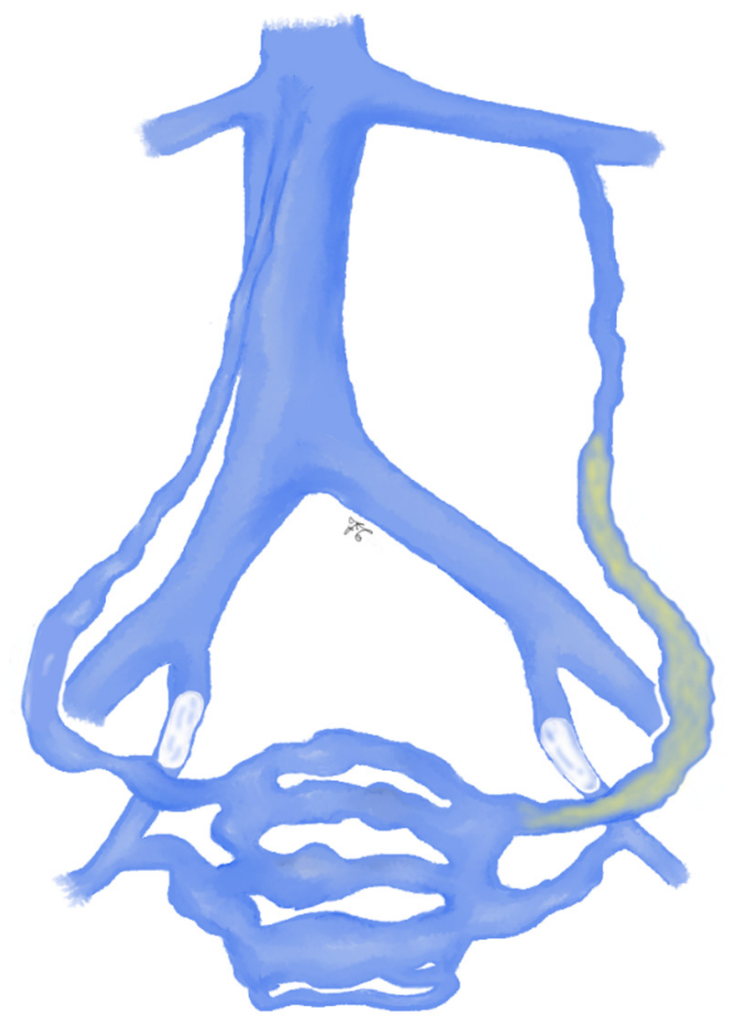

Figure 7. Drawing shows left ovarian vein embolization using the stop-flow foam sclerotherapy (SFFS) reported by Gandini et al. [82]: the sclerosing agent was injected into the pelvic vessels after having inflated the balloon catheter to occlude the major tributary vessels (hypogastric and/or ovarian veins) and excluding high-outflow venous collaterals.

This combined treatment (sclerosing agent and OB) was associated with an improvement of symptoms: pelvic and menstrual pain were significantly reduced in the follow-up up to one year, as well as urinary urgency and dyspareunia [82] in comparison to other previous studies, in which the OB was not used, that detected a clinical failure in $39 \%$ of cases and associated with pelvic varicosities with diameters greater than $5 \mathrm{~mm}$ [83]; the authors reported no significant complications related to the combined endovascular technique, but it was common for patients to experience colic-like pain soon after injection of the sclerosing agent [82].

Meneses et al. used sodium morrhuate as a sclerosing agent in a small cohort of women with PCS and relapsing varicose veins after surgery. In this study, the authors advanced the $\mathrm{OB}$ to the lower third of the sacroiliac joint or to the incompetent vein, respectively, for the embolization of gonadal or iliac veins; balloon insufflation was maintained for $5 \mathrm{~min}$ after the administration of sodium morrhuate and the procedure was completed with the placement of $14 \mathrm{~cm}$ length and 8 to $12 \mathrm{~cm}$ diameter metallic coils (Figure 8) [84]. The authors reported technical success in all patients, with significant improvement in venous scores clinical severity score (VCSS) and a visual analogue scale (VAS) for pain assessment; no major complications during or after the procedure were reported, but all treated patients experienced severe pelvic pain for approximately five minutes immediately after the administration of the sclerosing agent [84]. 


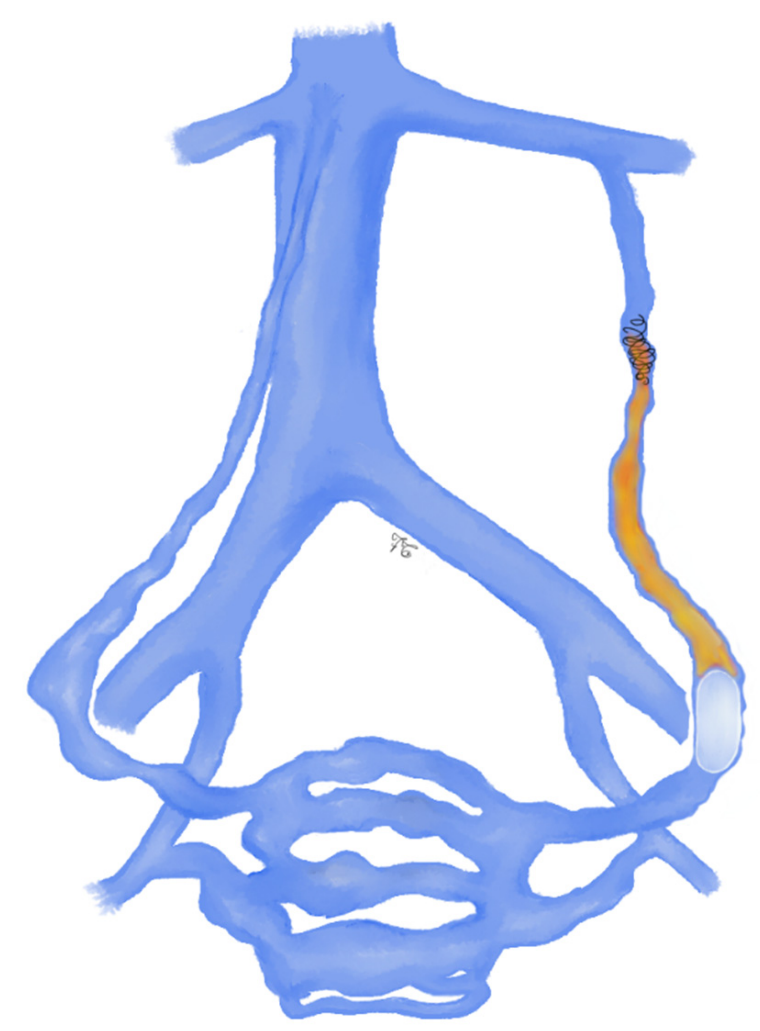

Figure 8. Drawing shows left ovarian vein embolization with sclerosing agent and coils: an occluding balloon is advanced to the lower third of the sacroiliac joint for the embolization of the gonadal vein; balloon insufflation was maintained for $5 \mathrm{~min}$ after the administration of sclerosant and the procedure was completed with the placement of metallic coils as reported by Meneses et al. [84].

It is difficult to establish whether unilateral embolization has a different result than a bilateral approach, as the studies and the opinions are heterogeneous and divergent [77]; however, it seems that there is no statistically significant difference in performing a unilateral or bilateral procedure, in terms of clinical outcome [77]. The clinical success of combined interventions on ovarian, internal iliac and varicose veins appears to be lower than for interventions limited to ovarian and iliac veins [85]. Finally, parity does not appear to be associated with difference in outcome in terms of clinical success in follow-up, regardless of the agent used [81].

The previous publications taken into consideration, the embolic materials used, the technical success rate, the recurrence rate and complications for pelvic congestion syndrome are summarized in Table 3.

Table 3. This table summarizes the publications taken into consideration, the embolic materials used, the technical success rate, the recurrence rate and complications for male pelvic congestion syndrome.

\begin{tabular}{|c|c|c|c|c|c|c|}
\hline Author & Study Design & Embolic Agent & Patients & $\begin{array}{l}\text { Technical } \\
\text { Success }\end{array}$ & $\begin{array}{l}\text { Recurrence } \\
\text { Rates }\end{array}$ & Complications \\
\hline \multicolumn{7}{|c|}{ Pelvic Congestion Syndrome Embolization } \\
\hline Basile et al. [78] & $\begin{array}{l}\text { Letter to the } \\
\text { editor/case } \\
\text { report }\end{array}$ & $\begin{array}{l}\text { Sclerosant + } \\
\text { AVP }\end{array}$ & 1 & $100 \%$ & - & - \\
\hline Capasso et al. [80] & $\begin{array}{l}\text { Observational } \\
\text { study } \\
\text { retrospective }\end{array}$ & $\begin{array}{l}\text { Glue and/or } \\
\text { macrocoils }\end{array}$ & 19 & $96.7 \%$ & NR & $\begin{array}{l}\text { Perivulvar ovarian vein } \\
\quad \text { perforation }(n=2)\end{array}$ \\
\hline
\end{tabular}


Table 3. Cont.

\begin{tabular}{|c|c|c|c|c|c|c|}
\hline Author & Study Design & Embolic Agent & Patients & $\begin{array}{l}\text { Technical } \\
\text { Success }\end{array}$ & $\begin{array}{l}\text { Recurrence } \\
\text { Rates }\end{array}$ & Complications \\
\hline \multicolumn{7}{|c|}{ Pelvic Congestion Syndrome Embolization } \\
\hline Gandini et al. [82] & $\begin{array}{l}\text { Observational } \\
\text { study } \\
\text { retrospective }\end{array}$ & Sclerosant & 26 & $100 \%$ & - & $\begin{array}{l}\text { Colic-like pain after the } \\
\text { injection of the sclerosing } \\
\text { agent }(n=26)\end{array}$ \\
\hline Laborda et al. [76] & $\begin{array}{l}\text { Observational } \\
\text { study } \\
\text { retrospective }\end{array}$ & Coils & 202 & $100 \%$ & $12.5 \%$ & $\begin{array}{l}\text { Groin hematoma }(n=6) \text {, coil } \\
\text { migration }(n=4) \text {, and } \\
\text { reaction to contrast media } \\
(n=1) .\end{array}$ \\
\hline Maleux et al. [81] & $\begin{array}{l}\text { Observational } \\
\text { study } \\
\text { retrospective }\end{array}$ & $\begin{array}{l}\text { Glue and } \\
\text { lipiodized oil } \\
\text { Glue and } \\
\text { microcoils } \\
(n=1)\end{array}$ & 41 & $98 \%$ & NR & $\begin{array}{l}\text { Migration of some fragments } \\
\text { of glue }(n=2)\end{array}$ \\
\hline Meneses et al. [84] & $\begin{array}{l}\text { Observational } \\
\text { study } \\
\text { retrospective }\end{array}$ & $\begin{array}{l}\text { Sclerosant and } \\
\text { coils }\end{array}$ & 10 & $100 \%$ & - & $\begin{array}{l}\text { No major complications, } \\
\text { pelvic pain for } 5 \text { min after } \\
\text { the sclerosant injection } \\
(n=10)\end{array}$ \\
\hline Pieri et al. [83] & $\begin{array}{l}\text { Observational } \\
\text { study } \\
\text { retrospective }\end{array}$ & Sclerosant & 33 & NR & $39 \%$ & NR \\
\hline
\end{tabular}

$\mathrm{NR}=$ Not reported .

\section{Conclusions}

For both male varicocele and pelvic congestion syndrome, different and heterogeneous endovascular treatment techniques have been reported for the local application of liquid or embolic agents, in some cases also in combination (coils and sclerosant, occluding balloon and sclerosant).

Some studies presented in this narrative review of the literature are detailed to allow them to be replicated in daily clinical practice. Overall, endovascular techniques proved to be relatively well tolerated because they were less invasive and with shorter hospitalizations than traditional surgery (often one-day setting). For the treatment of male varicocele with embolizing agents and endovascular techniques, a rather variable technical success rate is reported in the studies, ranging from $70 \%$ to $100 \%$, and recurrence rates of up to $16 \%$ of cases in the observational studies have been described: it should be noted that the recurrence rate is slightly higher than for surgical procedures, and this should be discussed with the patient undergoing the procedure. The treatment of PCS with endovascular embolism has a rather high success rate, reported between $96 \%$ and $100 \%$ in the series that we have reviewed, while the recurrence rate is highly variable according to the authors, ranging from $0 \%$ to $39 \%$ (worse results if only sclerosing agents are used)

The main complications reported in the literature, for both the treatment of male varicocele and PCS, are represented by the migration of embolizing media in distal sites, in collateral circulation or in the pulmonary circulation, but the consequences in all reported cases have been self-limiting.

In this scenario, the interventional radiologist becomes the main element of both the diagnostic and the therapeutic aspects.

Author Contributions: Conceptualization: F.T. and A.B.; methodology: F.T., G.D. and A.B.; formal analysis: F.T. and G.D.; investigation: F.T., G.D. and M.P.; data curation: F.T; writing—original draft: preparation: F.T. and G.D.; writing—review and editing: M.P., F.V. and A.B.; visualization: A.G., F.G., S.P. and M.V.; supervision: A.B.; project administration: A.B. All authors have read and agreed to the published version of the manuscript.

Funding: This research received no external funding. 
Institutional Review Board Statement: Not applicable.

Informed Consent Statement: Not applicable.

Data Availability Statement: Not applicable.

Conflicts of Interest: The authors declare no conflict of interest.

\section{References}

1. Bittles, M.A.; Hoffer, E.K. Gonadal Vein Embolization: Treatment of Varicocele and Pelvic Congestion Syndrome. Semin. Interview Radiol. 2008, 25, 261-270. [CrossRef]

2. Male Infertility Best Practice Policy Committee of the American Urological Association; Practice Committee of the American Society for Reproductive Medicine. Report on varicocele and infertility. Fertil. Steril. 2004, 82, 142-145. [CrossRef]

3. Meacham, R.B.; Townsend, R.R.; Rademacher, D.; Drose, J.A. The Incidence of Varicoceles in the General Population when Evaluated by Physical Examination, Gray Scale Sonography and Color Doppler Sonography. J. Urol. 1994, 151, $1535-1538$. [CrossRef]

4. Gat, Y.; Gornish, M.; Chakraborty, J.; Perlow, A.; Levinger, U.; Pasqualotto, F. Azoospermia and maturation arrest: Malfunction of valves in erect poster of humans leads to hypoxia in sperm production site. Andrologia 2010, 42, 389-394. [CrossRef] [PubMed]

5. Naughton, C.K.; Nangia, A.K.; Agarwal, A. Varicocele and male infertility: Part II: Pathophysiology of varicoceles in male infertility. Hum. Reprod. Updat. 2001, 7, 473-481. [CrossRef] [PubMed]

6. Spinelli, C.; Di Giacomo, M.; Piccolo, R.L.; Martin, A.; Messineo, A. The Role of Testicular Volume in Adolescents With Varicocele: The Better Way and Time of Surgical Treatment. J. Urol. 2010, 184, 1722-1726. [CrossRef]

7. Agarwal, A.; Sharma, R.; Harlev, A.; Esteves, S.C. Effect of varicocele on semen characteristics according to the new 2010 World Health Organization criteria: A systematic review and meta-analysis. Asian J. Androl. 2016, 18, 163-170. [CrossRef] [PubMed]

8. Paick, S.; Choi, W.S. Varicocele and Testicular Pain: A Review. World J. Men. Health 2019, 37, 4-11. [CrossRef] [PubMed]

9. Yamamoto, M.; Hibi, H. Effect of varicocelectomy on sperm parameters and pregnancy rate in patients with subclinical vari-cocele: A randomized prospective controlled study. J. Urol. 1996, 155, 1636-1638. [CrossRef]

10. Kroese, A.C.J.; De Lange, N.M.; Collins, J.; Evers, J.L.H. Surgery or embolization for varicoceles in subfertile men. Cochrane Database Syst. Rev. 2012, 10, CD000479. [CrossRef] [PubMed]

11. EAU Guidelines Office. EAU Guidelines. Edn. Presented at the EAU Annual Congress Barcelona; EAU Guidelines Office: Arnhem, The Netherlands, 2019; ISBN 978-94-92671-04-2.

12. Wallach, E.E.; Cockett, A.T.; Takihara, H.; Cosentino, M.J. The varicocele. Fertil. Steril. 1984, 41, 5-11. [CrossRef]

13. Dewire, D.M.; Thomas, A.J., Jr. Clinical outcome and cost comparison of percutaneous embolization and surgical ligation of varicocele. J. Androl. 1994, 15, 38S-42S.

14. Vanlangenhove, P.; De Keukeleire, K.; Everaert, K.; Van Maele, G.; Defreyne, L. Efficacy and Safety of Two Different n-Butyl-2Cyanoacrylates for the Embolization of Varicoceles: A Prospective, Randomized, Blinded Study. Cardiovasc. Interview Radiol. 2011, 35, 598-606. [CrossRef] [PubMed]

15. Vanlangenhove, P.; Everaert, K.; Van Maele, G.; Defreyne, L. Tolerance of glue embolization under local anesthesia in varicoceles: A comparative study of two different cyanoacrylates. Eur. J. Radiol. 2014, 83, 559-563. [CrossRef]

16. Lima, S.; Castro, M.; Costa, O. A New Method for the Treatment of Varicocele. Andrologia 2009, 10, 103-106. [CrossRef] [PubMed]

17. Iaccarino, V. A nonsurgical treatment of varicocele: Trans-catheter sclerotherapy of gonadal veins. Ann. Radiol. 1980, 23, 369-370.

18. Reyes, B.L.; Trerotola, S.O.; Venbrux, A.C.; Savader, S.J.; Lund, G.B.; Peppas, D.S.; Mitchell, S.E.; Gearhart, J.P.; White, R.I.; Osterman, F.A. Percutaneous Embolotherapy of Adolescent Varicocele: Results and Long-term Follow-up. J. Vasc. Interview Radiol. 1994, 5, 131-134. [CrossRef]

19. Urbano, J.; Cabrera, M.; Alonso-Burgos, A. Sclerosis and varicocele embolization with N-butyl cyanoacrylate: Experience in 41 patients. Acta Radiol. 2014, 55, 179-185. [CrossRef] [PubMed]

20. Bechara, C.F.; Weakley, S.M.; Kougias, P.; Athamneh, H.; Duffy, P.; Khera, M.; Kobayashi, K.; Lin, P.H. Percutaneous Treatment of Varicocele with Microcoil Embolization: Comparison of Treatment Outcome with Laparoscopic Varicocelectomy. Vascular 2009, 17, S129-S136. [CrossRef] [PubMed]

21. Kunnen, M. New techniques for embolisation of the internal spermatic vein: Intravenous tissue adhesive. RoFo 1980, 133, 625-629. [CrossRef]

22. Vanlangenhove, P. Contribution to the Pathophysiology and Treatment of Varicoceles. J. Belg. Soc. Radiol. 2018, 102, 22. [CrossRef]

23. Jing, Y.-X.; Wang, R.-H.; Liu, Z.-X.; Meng, Q.-Y. Analysis of internal spermatic vein embolization through catheter versus laparoscopic high ligation in treatment of left varicocele. Vascular 2020, 28, 583-590. [CrossRef] [PubMed]

24. Cornud, F.; Belin, X.; Amar, E.; Delafontaine, D.; Hélénon, O.; Moreau, J.F. Varicocele: Strategies in diagnosis and treatment. Eur. Radiol. 1999, 9, 536-545. [CrossRef]

25. Ali, A.; Wirth, S.; Treitl, K.M.; Treitl, M. Treatment of male varicoceles by transcatheter polidocanol foam sclerotherapy: Evaluation of clinical success, complications, and patients' satisfaction with regard to alternative techniques. Eur. Radiol. 2015, 25, 2889-2897. [CrossRef] [PubMed]

26. Iaccarino, V.; Venetucci, P. Interventional Radiology of Male Varicocele: Current Status. Cardiovasc. Interview Radiol. 2012, 35, 1263-1280. [CrossRef] [PubMed] 
27. Nicholson, T.; Basile, A. Pelvic Congestion Syndrome, Who Should We Treat and How? Tech. Vasc. Interview Radiol. 2006,9 , $19-23$. [CrossRef] [PubMed]

28. ACOG. Chronic Pelvic Pain: ACOG Practice Bulletin, Number 218. Obstet. Gynecol. 2020, 135, e98-e109. [CrossRef] [PubMed]

29. Freedman, J.; Ganeshan, A.; Crowe, P.M. Pelvic congestion syndrome: The role of interventional radiology in the treatment of chronic pelvic pain. Postgrad. Med. J. 2010, 86, 704-710. [CrossRef]

30. Hartung, O.; Grisoli, D.; Boufi, M.; Marani, I.; Hakam, Z.; Barthelemy, P.; Alimi, Y.S. Endovascular stenting in the treatment of pelvic vein congestion caused by nutcracker syndrome: Lessons learned from the first five cases. J. Vasc. Surg. 2005, 42, 275-280. [CrossRef]

31. Khan, T.A.; Rudolph, K.P.; Huber, T.S.; Fatima, J. May-Thurner syndrome presenting as pelvic congestion syndrome and vulvar varicosities in a nonpregnant adolescent. J. Vasc. Surg. Cases Innov. Tech. 2019, 5, 252-254. [CrossRef]

32. Ganeshan, A.; Upponi, S.; Hon, L.-Q.; Uthappa, M.C.; Warakaulle, D.R.; Uberoi, R. Chronic Pelvic Pain due to Pelvic Congestion Syndrome: The Role of Diagnostic and Interventional Radiology. Cardiovasc. Interview Radiol. 2007, 30, 1105-1111. [CrossRef]

33. Black, C.M.; Thorpe, K.; Venrbux, A.; Kim, H.S.; Millward, S.F.; Clark, T.W.; Kundu, S.; Martin, L.G.; Sacks, D.; York, J.; et al. Research Reporting Standards for Endovascular Treatment of Pelvic Venous Insufficiency. J. Vasc. Interview Radiol. 2010, 21, 796-803. [CrossRef]

34. Beard, R.; Pearce, S.; Highman, J.; Reginald, P. Diagnosis of pelvic varicosities in women with chronic pelvic pain. Lancet 1984, 324, 946-949. [CrossRef]

35. Lopez, A.J. Female Pelvic Vein Embolization: Indications, Techniques, and Outcomes. Cardiovasc. Interview Radiol. 2015, 38, 806-820. [CrossRef] [PubMed]

36. Vaidya, S.; Tozer, K.R.; Chen, J. An overview of embolic agents. Semin. Intervent. Radiol. 2008, 25, 204-215. [CrossRef] [PubMed]

37. Gianturco, C.; Anderson, J.H.; Wallace, S. Mechanical devices for arterial occlusion. Am. J. Roentgenol. 1975, 124, 428-435. [CrossRef] [PubMed]

38. Medsinge, A.; Zajko, A.; Orons, P.; Amesur, N.; Santos, E. A Case-Based Approach to Common Embolization Agents Used in Vascular Interventional Radiology. Am. J. Roentgenol. 2014, 203, 699-708. [CrossRef]

39. Lopera, J.E. The Amplatzer Vascular Plug: Review of Evolution and Current Applications. Semin. Interv. Radiol. 2015, 32, 356-369. [CrossRef] [PubMed]

40. White, R.I.; Ursic, T.A.; Kaufman, S.L.; Barth, K.H.; Kim, W.; Gross, G.S. Therapeutic Embolization with Detachable Balloons. Radiology 1978, 126, 521-523. [CrossRef]

41. Barth, K.H.; White, R.I.; Kaufman, S.L.; Terry, P.B.; Roland, J.M. Embolotherapy of pulmonary arteriovenous malformations with detachable balloons. Radiology 1982, 142, 599-606. [CrossRef]

42. Borie, E.; Rosas, E.; Kuramochi, G.; Etcheberry, S.; Olate, S.; Weber, B. Oral Applications of Cyanoacrylate Adhesives: A Literature Review. BioMed Res. Int. 2019, 2019, 8217602-8217606. [CrossRef] [PubMed]

43. De Souza, S.C.; Briglia, C.H. Comparative study of the use of ethyl cyanoacrylate adhesive and intracutaneous suture for cutaneous excision closure. Rev. Bras. Cirug. Plástica 2011, 26, 566-572.

44. Inal, S.; Yılmaz, N.; Nisbet, C.; Güvenç, T. Biochemical and histopathological findings of N-Butyl-2-Cyanoacrylate in oral surgery: An experimental study. Oral Surg. Oral Med. Oral Pathol. Oral Radiol. Endodontol. 2006, 102, e14-e17. [CrossRef] [PubMed]

45. Favard, N.; Moulin, M.; Fauque, P.; Bertaut, A.; Favelier, S.; Estivalet, L.; Michel, F.; Cormier, L.; Sagot, P.; Loffroy, R. Comparison of three different embolic materials for varicocele embolization: Retrospective study of tolerance, radiation and recurrence rate. Quant. Imaging Med. Surg. 2015, 5, 806-814. [PubMed]

46. Montanaro, L.; Arciola, C.; Cenni, E.; Ciapetti, G.; Savioli, F.; Filippini, F.; Barsanti, L. Cytotoxicity, blood compatibility and antimicrobial activity of two cyanoacrylate glues for surgical use. Biomaterials 2000, 22, 59-66. [CrossRef]

47. Loffroy, R.; Guiu, B.; Cercueil, J.-P.; Krause, D. Endovascular Therapeutic Embolisation: An Overview of Occluding Agents and their Effects on Embolised Tissues. Curr. Vasc. Pharmacol. 2009, 7, 250-263. [CrossRef]

48. Goldman, M.P.; Guex, J.-J. Mechanism of Action of Sclerotherapy. Sclerotherapy 2017, 173-199. [CrossRef]

49. Albanese, G.; Kondo, K.L. Pharmacology of Sclerotherapy. Semin. Interv. Radiol. 2010, 27, 391-399. [CrossRef]

50. Hardman, R.L.; Rochon, P.J. Role of Interventional Radiologists in the Management of Lower Extremity Venous Insufficiency. Semin. Interview Radiol. 2013, 30, 388-393. [CrossRef]

51. Saatci, I.; Geyik, S.; Yavuz, K.; Cekirge, H.S. Endovascular treatment of brain arteriovenous malformations with prolonged intranidal Onyx injection technique: Long-term results in 350 consecutive patients with completed endovascular treatment course. J. Neurosurg. 2011, 115, 78-88. [CrossRef]

52. De Keukeleire, K.; Vanlangenhove, P.; Okito, J.-P.K.; Hallaert, G.; Van Roost, D.; Defreyne, L. Transarterial embolization with ONYX for treatment of intracranial non-cavernous dural arteriovenous fistula with or without cortical venous reflux. $J$. Neurointerview Surg. 2011, 3, 224-228. [CrossRef]

53. Thelen, M.; Weißbach, L.; Franken, T. The treatment of idiopathic varicocoeles by transfemoral spiral occlusion of the left testicular vein (author's transl). RoFo 1979, 131, 24-29. [CrossRef] [PubMed]

54. Kuroiwa, T.; Hasuo, K. Transcatheter embolization of testicular vein for varicocele testis. Acta Radiol. 1991, 32, 311-314. [CrossRef] [PubMed]

55. Kwak, N.; Siegel, D. Imaging and Interventional Therapy for Varicoceles. Curr. Urol. Rep. 2014, 15. [CrossRef] 
56. Makris, G.C.; Efthymiou, E.; Little, M.; Boardman, P.; Anthony, S.; Uberoi, R.; Tapping, C. Safety and effectiveness of the different types of embolic materials for the treatment of testicular varicoceles: A systematic review. Br. J. Radiol. 2018, 91, 20170445. [CrossRef] [PubMed]

57. Puche-Sanz, I.; Flores-Martín, J.F.; Vázquez-Alonso, F.; Pardo-Moreno, P.L.; Cózar-Olmo, J.M. Primary treatment of painful varicocoele through percutaneous retrograde embolization with fibred coils. Andrology 2014, 2, 716-720. [CrossRef] [PubMed]

58. Bilreiro, C.; Donato, P.; Costa, J.; Agostinho, A.; Carvalheiro, V.; Caseiro-Alves, F. Varicocele embolization with glue and coils: A single center experience. Diagn. Interview Imaging 2017, 98, 529-534. [CrossRef]

59. Gazzera, C.; Rampado, O.; Savio, L.; Di Bisceglie, C.; Manieri, C.; Gandini, G. Radiological treatment of male varicocele: Technical, clinical, seminal and dosimetric aspects. Radiol. Med. 2006, 111, 449-458. [CrossRef]

60. White, R.I.; Kaufman, S.L.; Barth, K.H.; Kadir, S.; Smyth, J.W.; Walsh, P.C. Occlusion of varicoceles wih detachable balloons. Radiology 1981, 139, 327-334. [CrossRef]

61. Çil, B.; Peynircioglu, B.; Canyigit, M.; Akpinar, E.; Geyik, S.; Çiftçi, T. Peripheral vascular applications of the Amplatzer vascular plug. Diagn. Interview Radiol. 2008, 14, 35-39.

62. Brothers, M.F.; Kaufmann, J.C.; Fox, A.J.; Deveikis, J.P. n-Butyl 2-cyanoacrylate-substitute for IBCA in interventional neuroradiology: Histopathologic and polymerization time studies. Am. J. Neuroradiol. 1989, 10, 777-786.

63. Woodward, S.C.; Herrmann, J.B.; Cameron, J.L.; Brandes, G.; Pulaski, C.E.J.; Leonard, F. Histotoxicity of Cyanoacrylate Tissue Adhesive in the Rat. Ann. Surg. 1965, 162, 113-122. [CrossRef] [PubMed]

64. Matsumoto, T. Carcinogenesis and cyanoacrylate adhesives. JAMA 1967, 202, 1057. [CrossRef]

65. Sze, D.Y.; Kao, J.S. Persistent and recurrent postsurgical varicoceles: Venographic anatomy and treatment with N-butyl cyanoacrylate embolization. J. Vasc. Interview Radiol. 2008, 19, 539-545. [CrossRef] [PubMed]

66. Kolilekas, L.; Kalomenidis, I. Cyanoacrylate-related pulmonary embolismfollowing percutaneous varicocele embolization. South Med. J. 2008, 101, 1073-1074. [CrossRef] [PubMed]

67. Porst, H.; Bähren, W.; Lenz, M.; Altwein, J.E. Percutaneous Sclerotherapy of Varicoceles-an Alternative to Conventional Surgical Methods. BJU Int. 1984, 56, 73-78. [CrossRef] [PubMed]

68. Riedl, P. Selective phlebography and cathetersclerosation of the spermatic vein in primary varicocele. An angiographic-anatomical and clinical study (author's transl). Wien. Klin. Wochenschr. Suppl. 1979, 99, 3-20.

69. Basile, A.; Failla, G.; La Vignera, S.; Condorelli, R.A.; Calogero, A.; Vicari, E.; Granata, A.; Mundo, E.; Caltabiano, G.; Pizzarelli, M.; et al. Left spermatic vein retrograde sclerosis: Comparison between sclerosant agent injection through a diagnostic catheter versus through an occluding balloon catheter. Radiol. Med. 2015, 120, 483-488. [CrossRef]

70. Tessari, L.; Cavezzi, A. Preliminary experience with a new sclerosing foam in the treatment of varicose veins. Dermatol. Surg. 2001, 27, 58-60. [PubMed]

71. Saad, W.E.; Kitanosono, T.; Koizumi, J.; Hirota, S. The Conventional Balloon-Occluded Retrograde Transvenous Obliteration Procedure: Indications, Contraindications, and Technical Applications. Tech. Vasc. Interview Radiol. 2013, 16, 101-151. [CrossRef]

72. Di Bisceglie, C.; Bertagna, A. Varicocele sclerotherapy improves serum inhibin B levels and seminal parameters. Int. J. Androl. 2007, 30, 531-536. [CrossRef] [PubMed]

73. Gandini, R.; Konda, D.; Reale, C.A.; Pampana, E.; Maresca, L.; Spinelli, A.; Stefanini, M.; Simonetti, G. Male Varicocele: Transcatheter Foam Sclerotherapy with Sodium Tetradecyl Sulfate-Outcome in 244 Patients. Radiology 2008, 246, 612-618. [CrossRef]

74. Li, L.; Zeng, X.-Q.; Li, Y.-H. Safety and Effectiveness of Transcatheter Foam Sclerotherapy for Testicular Varicocele with a Fluoroscopic Tracing Technique. J. Vasc. Interview Radiol. 2010, 21, 824-828. [CrossRef] [PubMed]

75. Hansrani, V.; Abbas, A.; Bhandari, S.; Caress, A.-L.; Seif, M.; McCollum, C.N. Trans-venous occlusion of incompetent pelvic veins for chronic pelvic pain in women: A systematic review. Eur. J. Obstet. Gynecol. Reprod. Biol. 2015, 185, 156-163. [CrossRef] [PubMed]

76. Laborda, A.; Medrano, J.; De Blas, I.; Urtiaga, I.; Carnevale, F.C.; De Gregorio, M.A. Endovascular Treatment of Pelvic Congestion Syndrome: Visual Analog Scale (VAS) Long-Term Follow-up Clinical Evaluation in 202 Patients. Cardiovasc. Interview Radiol. 2013, 36, 1006-1014. [CrossRef]

77. Rizer, M.; Alexander, R.; Sharpe, E.; Rochon, P.J.; Brown, C.L. Pelvic Congestion Syndrome: Systematic Review of Treatment Success. Semin. Interview Radiol. 2018, 35, 35-40. [CrossRef]

78. Basile, A.; Marletta, G.; Tsetis, D.; Patti, M.T. The Amplatzer Vascular Plug Also for Ovarian Vein Embolization. Cardiovasc. Interview Radiol. 2008, 31, 446-447. [CrossRef]

79. Kim, H.S.; Malhotra, A.D.; Rowe, P.C.; Lee, J.M.; Venbrux, A.C. Embolotherapy for Pelvic Congestion Syndrome: Long-term Results. J. Vasc. Interview Radiol. 2006, 17, 289-297. [CrossRef]

80. Capasso, P.; Simons, C.; Trotteur, G.; Dondelinger, R.F.; Henroteaux, D.; Gaspard, U. Treatment of symptomatic pelvic varices by ovarian vein embolization. Cardiovasc. Interview Radiol. 1997, 20, 107-111. [CrossRef]

81. Maleux, G.; Stockx, L.; Wilms, G.; Marchal, G. Ovarian Vein Embolization for the Treatment of Pelvic Congestion Syndrome: Long-Term Technical and Clinical Results. J. Vasc. Interview Radiol. 2000, 11, 859-864. [CrossRef]

82. Gandini, R.; Konda, D.; Abrignani, S.; Chiocchi, M.; Da Ros, V.; Morosetti, D.; Simonetti, G. Treatment of Symptomatic High-Flow Female Varicoceles with Stop-flow Foam Sclerotherapy. Cardiovasc. Interview Radiol. 2014, 37, 1259-1267. [CrossRef] 
83. Pieri, S.; Agresti, P.; Morucci, M.; Medici, L.D. Percutaneous treatment of pelvic congestion syndrome. Radiol. Med. 2003, 105, 76-82. [PubMed]

84. Meneses, L.; Fava, M.; Diaz, P.; Andia, M.; Tejos, C.; Irarrazabal, P.; Uribe, S. Embolization of Incompetent Pelvic Veins for the Treatment of Recurrent Varicose Veins in Lower Limbs and Pelvic Congestion Syndrome. Cardiovasc. Interview Radiol. 2012, 36, 128-132. [CrossRef] [PubMed]

85. Basile, A.; Failla, G.; Gozzo, C. Pelvic Congestion Syndrome. Semin. Ultrasound CT MRI 2021, 42, 3-12. [CrossRef] [PubMed] 